\title{
Dietary management of childhood diarrhea in low- and middle-income countries: a systematic review
}

Michelle F Gaffey ${ }^{1,2}$, Kerri Wazny ${ }^{1}$, Diego G Bassani ${ }^{1,3}$, Zulfiqar A Bhutta $^{1,4^{*}}$

\begin{abstract}
Background: Current WHO guidelines on the management and treatment of diarrhea in children strongly recommend continued feeding alongside the administration of oral rehydration solution and zinc therapy, but there remains some debate regarding the optimal diet or dietary ingredients for feeding children with diarrhea.

Methods: We conducted a systematic search for all published randomized controlled trials evaluating food-based interventions among children under five years old with diarrhea in low- and middle-income countries. We classified 29 eligible studies into one or more comparisons: reduced versus regular lactose liquid feeds, lactose-free versus lactose-containing liquid feeds, lactose-free liquid feeds versus lactose-containing mixed diets, and commercial/ specialized ingredients versus home-available ingredients. We used all available outcome data to conduct randomeffects meta-analyses to estimate the average effect of each intervention on diarrhea duration, stool output, weight gain and treatment failure risk for studies on acute and persistent diarrhea separately.
\end{abstract}

Results: Evidence of low-to-moderate quality suggests that among children with acute diarrhea, diluting or fermenting lactose-containing liquid feeds does not affect any outcome when compared with an ordinary lactosecontaining liquid feeds. In contrast, moderate quality evidence suggests that lactose-free liquid feeds reduce duration and the risk of treatment failure compared to lactose-containing liquid feeds in acute diarrhea. Only limited evidence of low quality was available to assess either of these two approaches in persistent diarrhea, or to assess lactose-free liquid feeds compared to lactose-containing mixed diets in either acute or persistent diarrhea. For commercially prepared or specialized ingredients compared to home-available ingredients, we found low-tomoderate quality evidence of no effect on any outcome in either acute or persistent diarrhea, though when we restricted these analyses to studies where both intervention and control diets were lactose-free, weight gain in children with acute diarrhea was shown to be greater among those fed with a home-available diet.

Conclusions: Among children in low- and middle-income countries, where the dual burden of diarrhea and malnutrition is greatest and where access to proprietary formulas and specialized ingredients is limited, the use of locally available age-appropriate foods should be promoted for the majority of acute diarrhea cases. Lactose intolerance is an important complication in some cases, but even among those children for whom lactose avoidance may be necessary, nutritionally complete diets comprised of locally available ingredients can be used at least as effectively as commercial preparations or specialized ingredients. These same conclusions may also apply to the dietary management of children with persistent diarrhea, but the evidence remains limited.

\footnotetext{
* Correspondence: zulfiqar.bhutta@aku.edu

${ }^{1}$ Centre for Global Child Health, The Hospital for Sick Children, Toronto, ON,

Canada

Full list of author information is available at the end of the article
}

\section{Biomed Central}

(C) 2013 Gaffey et al; licensee BioMed Central Ltd. This is an Open Access article distributed under the terms of the Creative Commons Attribution License (http://creativecommons.org/licenses/by/2.0), which permits unrestricted use, distribution, and reproduction in any medium, provided the original work is properly cited. 


\section{Background}

While childhood diarrhea mortality has declined steadily since the 1980s, diarrheal disease remains the third leading cause of death among children under-five globally. An estimated 800,000 under-five deaths were attributable to diarrhea in 2010 , accounting for $11 \%$ of all underfive deaths, with about $80 \%$ of these diarrheal deaths occurring in the African and Southeast Asian WHO regions [1].

Current WHO guidelines on the management and treatment of diarrhea in children strongly recommend continued feeding alongside administration of oral rehydration solutions, plus zinc therapy [2,3]. The benefit of early feeding of children with diarrhea has been known since the late 1940s [4], with clinical and communitybased studies since then providing further evidence to support early and continued feeding during diarrhea [5-7]. A recent systematic review found no evidence to suggest that early compared to delayed feeding in acute diarrhea increases the risk of complications [7], and continued feeding from the early stage of a diarrheal episode can mitigate the consequences of reduced absorption and increased loss of nutrients, and thereby also limit the cumulative and longer-term effects of diarrhea morbidity on child growth [8].

Continued feeding is now widely accepted as a key component of appropriate treatment for childhood diarrhea, but with the exception of consensus on continued breastfeeding, there remains some debate regarding the optimal diet or dietary ingredients for hastening recovery and maintaining nutritional status in children with diarrhea $[8,9]$. Lactose malabsorption is a common complication of diarrhea [10], especially among malnourished children [11], but limiting milk intake among young children can promote further nutritional deficiency if substitute sources of protein and energy are not consumed sufficiently. Commercial preparations of soy-based or other lactose-free formulations may be effective, but they are not routinely available to households in the settings in which most diarrhea morbidity and mortality occur, where the use of locally available foods to comprise appropriate treatment diets is far more feasible. Earlier reviews of the literature have narratively and/or quantitatively summarized evidence for the effectiveness of several dietary regimens for managing childhood diarrhea $[6,8,9,12-14]$. In the present review we sought to update some of these analyses with particular reference to children in low- and middle-income countries, and then to explicitly compare the use of costly commercial or specialized preparations with diets of locally available foods on which the home management of childhood diarrhea in low- and middle-income countries could more feasibly be based.

\section{Objective}

This review aimed to assess the relative effectiveness of several approaches to the dietary management of childhood diarrhea in hastening recovery and improving nutritional status in children with diarrhea in low- and middle-income countries.

\section{Methods}

We used the PICO (Population, Intervention, Comparison, Outcome) approach to frame our research question, establish our inclusion criteria and develop our search strategy. The population of interest was children under five years of age with diarrhea in low- and middleincome countries. We sought to find and include all randomized controlled trials in this population that evaluated continued feeding with one specified diet compared to at least one other specified diet. For analysis, individual studies were then grouped into broader sets of dietary comparisons, as described below. We considered three continuous outcomes of interest, ideally measured from the start of the dietary intervention (following initial correction of dehydration) until the resolution of diarrhea, but measured over shorter time periods in some studies: duration of diarrhea, stool output, and weight change. We also considered the proportion of participants experiencing treatment failure during the study period. The definition of treatment failure was that used by the individual study authors and typically included the need for a change in clinical management, including a change of diet. Specific criteria for treatment failure included sustained diarrhea beyond a certain period, worsening of diarrhea, or recurrent dehydration. If the study authors did not explicitly define treatment failure but data were available for an outcome consistent with the need for a change in clinical management, we used these.

\section{Search strategy}

We searched the following electronic databases initially in December 2011 and finally in September 2012, with no restriction on date or language: Medline, Embase, AMED, LILACS, WHOLIS, African Index Medicus, Index Medicus for the Eastern Mediterranean Region, Index Medicus for South-East Asia Region, and Western Pacific Region Index Medicus. Our search inputs combined various terms for the four concepts of diarrhea, child/infant/newborn, feeding/food/diet and trial/comparative study. The specific inputs used for Medline, Embase and AMED are given in Additional File 1. We also examined reference lists of previous reviews related to dietary management of childhood diarrhea to identify any potentially relevant publications not found through the electronic search. 


\section{Search results and study selection}

All titles and abstracts returned by the electronic search as well as the reference lists of previous related reviews were independently screened for relevance in duplicate. The full-text reports of all titles screened as relevant were then independently examined in duplicate, to determine each study's eligibility with respect to the review inclusion criteria - i.e. randomized controlled trials that evaluated food-based dietary interventions among children under five years of age with diarrhea in low- and middle-income countries. We based country eligibility on the World Bank's country classification by income [15]. Trials evaluating probiotics, micronutrient supplementation, oral rehydration solution formulations, or other non-food-based nutritional treatment of diarrhea were not included unless the effects of the food-based components included in these trials could be isolated. Studies that met the inclusion criteria but did not report on outcomes of interest to this review were included as eligible but did not contribute to the quantitative analyses.

\section{Data abstraction}

Data from each eligible study were independently abstracted in duplicate using a data collection form to capture information on study characteristics, participant characteristics, components of the diets compared, any co-interventions, quantitative results reported for each outcome of interest (overall and by sub-group, if presented), key conclusions and comments on study limitations made by study authors, and funding sources. The two sets of abstracted data were compared and any discrepancies were resolved through discussion and by consulting a third reviewer where necessary. Attempts were made to contact study authors by email for missing information on outcomes. Where studies reported weight change or stool output for separate periods during the study but not for the overall study period, we used data from the earliest post-rehydration period reported [16]. In two studies that reported standard deviations for the mean baseline and endline weights but not for the mean change in weight $[17,18]$, we imputed standard deviations for the mean change assuming a correlation of 0.75 between the baseline and endline standard deviations [19]. Alternative imputed estimates assuming higher and lower correlation did not affect the pooled estimates to which these data contributed. The abstracted data for all studies included in the quantitative data synthesis are presented in Additional File 2.

\section{Intervention comparisons}

We identified the comparisons for this review based on the literature on lactose reduction and avoidance in diarrhea and on home-based dietary management of diarrhea, but we were also constrained by the results of our search strategy. Once the detail of each diet evaluated in each eligible study was abstracted, we classified each study into one or more possible dietary comparisons. The following four comparisons of interest were finally identified both for their substantive focus and for the number of eligible studies with which they were compatible:

1) Liquid feeds: reduced lactose versus regular lactose

2) Liquid feeds: lactose-free versus lactose-containing

3) Lactose-free liquid feeds versus lactose-containing mixed diets

4) Diets that include commercial preparations or specialized ingredients versus diets comprised of homeavailable ingredients

The comparison definitions, the classification of included studies by comparison, and details of the diets evaluated in each study are given in Table 1 .

\section{Quality assessment}

We applied the CHERG adaptation of the GRADE technique [20] to assess the overall quality of evidence for each outcome for each comparison. First, each study was graded on a four-point continuum from "high" to "very low", with the initial "high" score for randomized, controlled design being adjusted downward if necessary, as indicated by the assessment of the study's methods (including randomization and allocation concealment procedures, blinding, completeness of outcome ascertainment and outcome reporting, and other criteria) on risk of bias. Secondly, an overall evidence score on the same scale was then assigned for each outcome for each comparison, taking into account the quality of the studies included, the volume and consistency of results across studies, the size of the pooled effect estimate, and the strength of evidence for that estimate as indicated by its p-value.

\section{Quantitative analysis}

For each meta-analysis, we first stratified studies by participants' duration of diarrhea at study enrolment: acute (duration of 7 days or less) or persistent (duration of 14 days or more). No studies focused specifically on prolonged diarrhea (duration between 7 and 14 days). Assuming the variety of diets evaluated in each comparison were unlikely to produce the same, fixed intervention effect, we decided a priori to use random-effects models for all meta-analyses to instead estimate the average intervention effect. For the three continuous outcomes (duration of diarrhea, stool output, weight change) we estimated the standardized mean difference, which allows for data on the same outcome but measured on different scales to be pooled in one meta-analysis. For the dichotomous outcome of treatment failure we estimated the risk ratio. We assessed the presence of heterogeneity by 
Table 1 Comparison definitions, study diets, and inventory of available outcome data

\begin{tabular}{|c|c|c|c|c|c|c|}
\hline \multirow[t]{2}{*}{ Study ID } & \multirow[t]{2}{*}{ Intervention diet } & \multirow[t]{2}{*}{ Control diet } & \multicolumn{4}{|c|}{ Available outcome data } \\
\hline & & & Duration & $\begin{array}{l}\text { Stool } \\
\text { output }\end{array}$ & $\begin{array}{l}\text { Weight } \\
\text { change }\end{array}$ & $\begin{array}{l}\text { Treatment } \\
\text { failure }\end{array}$ \\
\hline \multicolumn{7}{|c|}{$\begin{array}{l}\text { Comparison 1. Liquid feeds: Reduced lactose versus Regular lactose } \\
\text { Comparison of diets that include lactose-containing liquid feeds, where the intervention liquid feed contains less lactose than the control } \\
\text { liquid feed }\end{array}$} \\
\hline $\begin{array}{l}\text { Bhatnagar } \\
1998\end{array}$ & Fermented formula + rice-lentil-oil gruel & Milk formula + rice-lentil-oil gruel & & & & Y \\
\hline Chew 1993 & $\begin{array}{l}\text { Gradually increased concentration of milk } \\
\text { formula }\end{array}$ & Full strength milk formula & Y & Y & Y & Y \\
\hline Ibanez 1986 & Acidified milk formula & Milk formula & & Y & & \\
\hline Lifshitz 1991 & Diluted cow's milk & Cow's milk formula & & & & Y \\
\hline $\begin{array}{l}\text { Pichaipat } \\
1986\end{array}$ & $\begin{array}{l}\text { Gradually increased concentration of milk } \\
\text { formula }\end{array}$ & Full strength milk formula & & & & Y \\
\hline $\begin{array}{l}\text { Ransome } \\
1984\end{array}$ & $\begin{array}{l}\text { Gradually increased concentration of cow's } \\
\text { milk }\end{array}$ & Full-strength cow's milk & Y & & & Y \\
\hline Singh 1987 & Yogurt & Milk & Y & & & \\
\hline $\begin{array}{l}\text { Touhami } \\
1989\end{array}$ & Half strength milk or milk formula & Full strength milk or milk formula & Y & Y & Y & Y \\
\hline $\begin{array}{l}\text { Touhami } \\
1992\end{array}$ & $\begin{array}{l}\text { Fermented milk formula }+ \text { cereals }+ \\
\text { vegetable soup }\end{array}$ & Milk formula + cereals + vegetable soup & & Y & Y & Y \\
\hline
\end{tabular}

Comparison 2. Liquid feeds: Lactose-free versus Lactose-containing

Comparison of diets that include liquid feeds, where the intervention liquid feed is lactose-free and the control liquid feed is lactosecontaining

\begin{tabular}{|c|c|c|c|c|c|c|}
\hline Brown 1991 & $\begin{array}{l}\text { i) Lactose-hydrolyzed powdered milk + corn } \\
\text { syrup solids; ii) Lactose-hydrolyzed powdered } \\
\text { milk + corn syrup solids, with wheat noodles }\end{array}$ & $\begin{array}{l}\text { i) Powdered milk + corn syrup solids; ii) } \\
\text { Powdered milk + corn syrup solids, with } \\
\text { wheat noodles }\end{array}$ & Y & Y & Y & Y \\
\hline Fayad 1999 & Soy-based formula with sucrose & Soy-based formula with lactose & Y & & Y & Y \\
\hline $\begin{array}{l}\text { Haffejee } \\
1990\end{array}$ & Soy-based formula & Cow's milk formula & Y & & & \\
\hline Lifshitz 1991 & $\begin{array}{l}\text { i) Lactose-free sodium caseinate formula; ii) } \\
\text { Lactose-free casein hydrolysate formula; iii) } \\
\text { Soy-based formula }\end{array}$ & $\begin{array}{l}\text { i) Diluted cow's milk; ii) Cow's milk } \\
\text { formula }\end{array}$ & & & & Y \\
\hline Lozano 1994 & $\begin{array}{l}\text { Lactose-free casein-based formula plus non- } \\
\text { milk food }\end{array}$ & $\begin{array}{l}\text { Cow's milk formula plus same non-milk } \\
\text { food }\end{array}$ & Y & & & Y \\
\hline Naidoo 1981 & Soy-based formula & Cow's milk formula & & & & Y \\
\hline Penny 1989 & $\begin{array}{l}\text { Lactose-hydrolyzed powdered milk + corn } \\
\text { syrup solids }\end{array}$ & Powdered milk + corn syrup solids & & & & Y \\
\hline Rajah 1988 & $\begin{array}{l}\text { i) Lactose-free casein-based formula; ii) Soy- } \\
\text { based formula; iii) Lactose-free hydrolyzed } \\
\text { whey formula }\end{array}$ & Cow's milk formula & & Y & & Y \\
\hline Romer 1989 & Lactose-free semi-elemental formula & Cow's milk & & & Y & Y \\
\hline $\begin{array}{l}\text { Simakachorn } \\
2004\end{array}$ & Soy-based formula + rice gruel & Cow's milk formula + rice gruel & Y & Y & Y & Y \\
\hline
\end{tabular}

Comparison 3. Lactose-free liquid feeds versus Lactose-containing mixed diets

Comparison of lactose-free liquid feeds with mixed diets containing lactose

\begin{tabular}{|c|c|c|c|c|c|c|}
\hline Alarcon 1991 & Soy-based formula & $\begin{array}{l}\text { Potato flour + milk powder + carrot flour } \\
+ \text { veg oil + sugar }\end{array}$ & & & & Y \\
\hline Bhutta 1991 & Soy-based formula & Rice + lentils + cottonseed oil + yogurt & & Y & Y & Y \\
\hline Bhutta 1994 & Soy-based formula & $\begin{array}{l}\text { Rice }+ \text { lentils }+ \text { cottonseed oil }+ \text { yogurt }+ \\
\text { diluted buffalo milk }\end{array}$ & Y & Y & Y & Y \\
\hline Brown 1991 & $\begin{array}{l}\text { Lactose-hydrolyzed powdered milk + corn } \\
\text { syrup solids }\end{array}$ & $\begin{array}{l}\text { Powdered milk + corn syrup solids, with } \\
\text { wheat noodles }\end{array}$ & Y & Y & Y & Y \\
\hline
\end{tabular}

Comparison 4. Commercially prepared or specialized ingredients versus Home-available ingredients

Comparison of commercial preparations or specialized ingredients with diets comprised of home-available ingredients

Alarcon 1991 Soy-based formula

i) Wheat flour + pea flour + carrot flour + 


\begin{tabular}{|c|c|c|c|c|c|c|}
\hline Alarcon 1992 & $\begin{array}{l}\text { Rice }+ \text { vegetable oil }+ \text { soy protein isolate }+ \\
\text { corn syrup solids }\end{array}$ & Rice + vegetable oil +white beans & & & & Y \\
\hline Bhan 1988 & Cow's milk formula & Rice + lentil + sugar + coconut oil & Y & & Y & Y \\
\hline Bhutta 1991 & Soy-based formula & Rice + lentils + cottonseed oil + yogurt & & Y & Y & Y \\
\hline Bhutta 1994 & Soy-based formula & $\begin{array}{l}\text { Rice }+ \text { lentils + cottonseed oil + yogurt + } \\
\text { diluted buffalo milk }\end{array}$ & Y & Y & Y & Y \\
\hline Brown 1991 & $\begin{array}{l}\text { i) Lactose-hydrolyzed powdered milk + corn } \\
\text { syrup solids; ii) Lactose-hydrolyzed powdered } \\
\text { milk + corn syrup solids, with wheat noodles }\end{array}$ & $\begin{array}{l}\text { i) Powdered milk + corn syrup solids; ii) } \\
\text { Powdered milk + corn syrup solids, with } \\
\text { wheat noodles }\end{array}$ & Y & Y & Y & Y \\
\hline Carias 1999 & Soy-based formula & Lactose-free chicken-based formula & & Y & Y & \\
\hline Godard 1989 & $\begin{array}{l}\text { Hydrolyzed lactalbumin + dextrin-maltrose + } \\
\text { sunflower oil + carrots }\end{array}$ & $\begin{array}{l}\text { Chicken }+ \text { dextrin-maltrose }+ \text { sunflower } \\
\text { oil }+ \text { carrots }\end{array}$ & Y & & & \\
\hline Grange 1994 & Soy-based formula & $\begin{array}{l}\text { Fermented maize flour }+ \text { toasted cowpea } \\
\text { flour }+ \text { palm oil }+ \text { sugar }\end{array}$ & & & & Y \\
\hline Lifshitz 1991 & $\begin{array}{l}\text { i) Lactose-free sodium caseinate formula; ii) } \\
\text { Lactose-free casein hydrolysate formula; iii) } \\
\text { Soy-based formula; iv) Cow's milk formula }\end{array}$ & Diluted cow's milk & & & & Y \\
\hline $\begin{array}{l}\text { Maulen- } \\
\text { Radovan } \\
1994\end{array}$ & Soy-based formula & $\begin{array}{l}\text { Rice }+ \text { chicken }+ \text { carrots }+ \text { beans }+ \\
\text { vegetable oil }\end{array}$ & & Y & Y & Y \\
\hline Nurko 1997 & i) Elemental formula: ii) Soy-based formula & Chicken + sugar + minerals + cooking oil & Y & Y & Y & Y \\
\hline Penny 1989 & $\begin{array}{l}\text { Lactose-hydrolyzed powdered milk + corn } \\
\text { syrup solids }\end{array}$ & Powdered milk + corn syrup solids & & & & Y \\
\hline Romer 1989 & Lactose-free semi-elemental formula & Cow's milk & & & Y & Y \\
\hline $\begin{array}{l}\text { Santosham } \\
1990\end{array}$ & i) Soy-based formula; ii) Rice-based formula & Liquefied boiled rice & Y & Y & $Y$ & $Y$ \\
\hline
\end{tabular}

examining the extent of confidence interval overlap in the forest plots and we quantified heterogeneity using the I-squared statistic, with an I-squared value of $50 \%$ or greater indicating moderate heterogeneity [21]. All metaanalyses were conducted in Review Manager 5.1.

\section{Results}

\section{Identification of studies}

Our electronic search strategy returned 4586 titles and abstracts from which 195 papers were screened as relevant and retrieved for full-text examination (Figure 1). An additional 11 relevant titles were identified from the reference lists of previous reviews related to our topic. After excluding 139 papers that either did not meet our inclusion criteria, did not apply co-interventions equally across all study groups or were additional reports of already included studies, the remaining 67 studies were assessed as eligible for inclusion. Of these, 38 studies either included dietary comparisons that were not consistent with any of the four comparisons on which this review focused or did not report sufficient data for any four outcomes of interest, or both (Additional File 3). The remaining 29 studies were included in the quantitative data synthesis (Table 1 ).

\section{Quantitative data synthesis}

The results from the meta-analyses conducted for each comparison and outcome are presented below, stratified by duration of diarrhea at study enrolment. The forest plots generated for all meta-analyses are presented in Additional File 4.

\section{Liquid feeds: reduced lactose versus regular lactose Acute diarrhea}

Eight trials among children with acute diarrhea compared diets comprised partially or wholly of lactosecontaining liquid feeds, where the lactose content of one liquid feed was reduced compared to the lactose content of the other. Five studies [22-26] compared diluted to undiluted milk products, and three studies [27-29] compared acidified or fermented milk products to regular milk products. One study allowed non-milk complementary foods in addition to the intervention and control liquid feeds, with both comparison groups receiving the identical complementary foods [27]. All studies excluded severely malnourished children.

The pooled results from four studies reporting on diarrhea duration $[22,25,26,29]$, three studies reporting on stool output $[22,26,28]$, two studies reporting on weight change $[22,26]$ and six studies reporting on treatment failure [22-27] showed no statistically significant effects of reduced lactose liquid feeds on any outcome (Table 2). The overall quality of evidence was assessed as low for the outcome of duration and moderate for the stool output, weight change and treatment failure outcomes. 


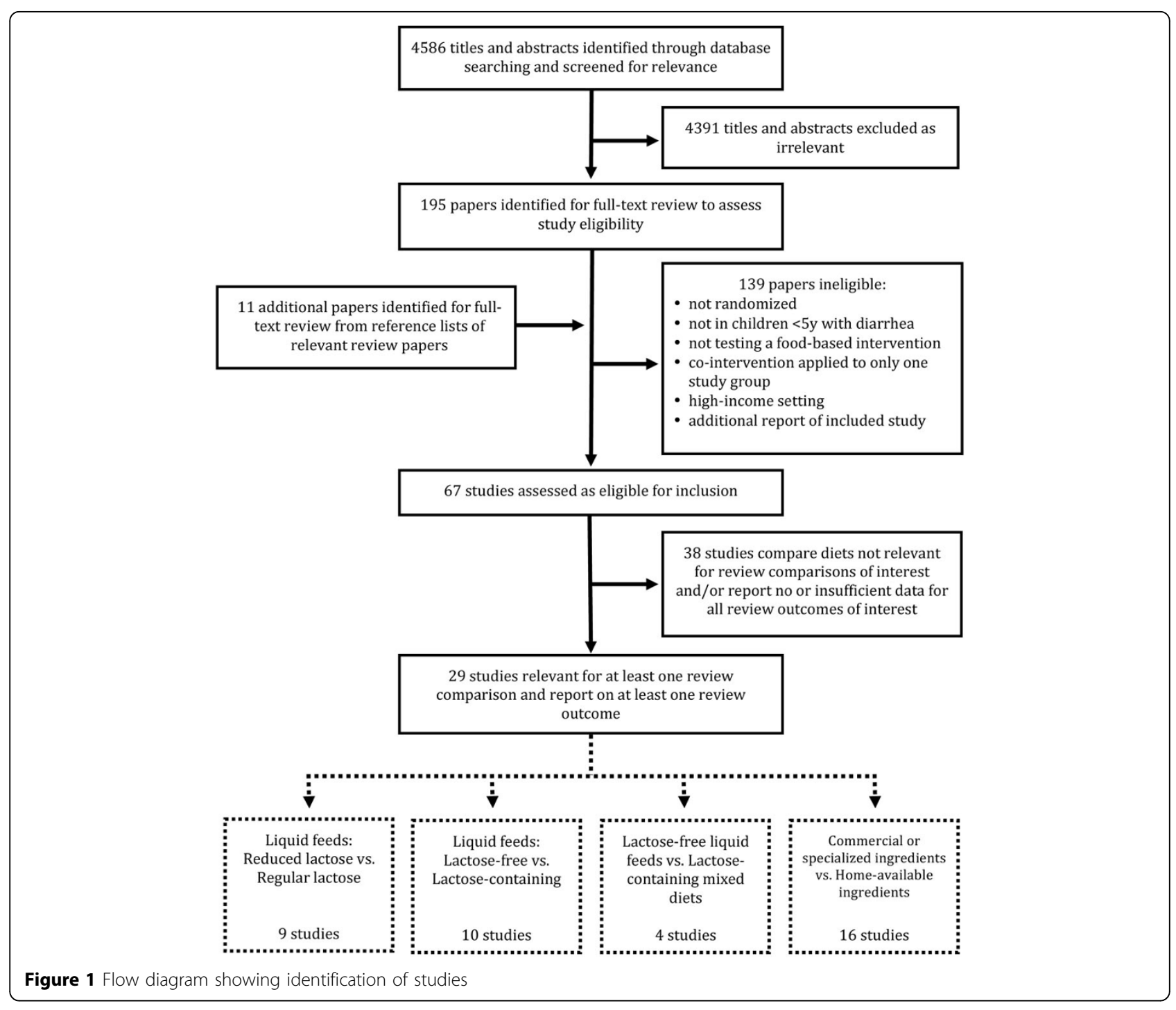

\section{Persistent diarrhea}

A single study among well-nourished children with persistent diarrhea compared a fermented milk formula with a regular milk formula, with both study groups also receiving cereals and vegetable soup [30]. Data on diarrhea duration were not reported, and no statistically significant effect was shown for either stool output or weight change. A large and statistically significant reduction in the risk of treatment failure was reported for the use of yogurt compared to milk (Risk ratio (RR): 0.27; 95\%CI: 0.10 to $0.74 ; \mathrm{p}=0.01$ ), but the overall quality of evidence was assessed as low given that no other studies were included in the analysis.

\section{Liquid feeds: lactose-free versus lactose-containing Acute diarrhea}

Eight trials among children with acute diarrhea compared diets comprised partially or wholly of liquid feeds, where the liquid feed in one study group was lactosefree and the liquid feed in the other contained lactose. Six studies compared cow's milk or cow's milk-based formula with soy-based, casein-based or whey-based formulas [16,23,31-34], one study compared regular milk to milk in which at least $95 \%$ of the lactose had been hydrolyzed [35], and one study compared soy-based formulas with and without added lactose [36]. Three studies allowed non-milk complementary foods in addition to the intervention and control liquid feeds, with complementary foods given identically across comparison groups $[16,32,36]$. All studies excluded severely malnourished children.

The pooled result from five studies [16,31,32,35,36] showed a statistically significant effect of lactose-free liquid feeds on reducing diarrhea duration (SMD: -0.36; 95\%CI: -0.62 to $-0.10 ; \mathrm{p}=0.008$ ) (Table 3 ). Effect sizes and their statistical significance varied across studies but 
Table 2 Quality assessment of studies on reduced lactose versus regular lactose liquid feeds

\begin{tabular}{|c|c|c|c|c|c|c|c|c|c|}
\hline \multirow[b]{2}{*}{$\begin{array}{l}\text { Number } \\
\text { of } \\
\text { studies }\end{array}$} & \multirow[b]{2}{*}{$\begin{array}{l}\text { Diarrhea } \\
\text { mode }\end{array}$} & \multicolumn{5}{|c|}{ QUALITY ASSESSMENT } & \multicolumn{3}{|c|}{ SUMMARY OF FINDINGS } \\
\hline & & Design & Limitations & Consistency & $\begin{array}{c}\text { Generalizability to population of } \\
\text { interest }\end{array}$ & $\begin{array}{l}\text { Overall } \\
\text { quality of } \\
\text { evidence }\end{array}$ & $\begin{array}{l}\text { Number of } \\
\text { events in } \\
\text { intervention } \\
\text { group }\end{array}$ & $\begin{array}{l}\text { Number of } \\
\text { events in } \\
\text { control group }\end{array}$ & $\begin{array}{l}\text { Effect size }(95 \% \\
\text { Cl) }\end{array}$ \\
\hline \multicolumn{6}{|c|}{ OUTCOME: DURATION OF DIARRHEA } & & & & $\begin{array}{c}\text { Standardized } \\
\text { Mean Difference }\end{array}$ \\
\hline 4 & Acute & $\mathrm{RCT}$ & Study quality ranges from low to high & $\begin{array}{l}\text { Heterogeneous } \\
\qquad\left(1^{2}=82 \%\right)\end{array}$ & $\begin{array}{c}\text { Infants and young children }(\leq 36 \mathrm{~m}) \\
\text { with acute diarrhea, not severely } \\
\text { malnourished, in LMICs }\end{array}$ & Low & - & - & $-0.49[-1.04,0.07]$ \\
\hline 0 & Persistent & RCT & No studies & - & - & - & - & - & - \\
\hline \multicolumn{7}{|c|}{ OUTCOME: STOOL OUTPUT } & & & $\begin{array}{c}\text { Standardized } \\
\text { Mean Difference }\end{array}$ \\
\hline 3 & Acute & $\mathrm{RCT}$ & $\begin{array}{l}\text { Study quality ranges from moderate to } \\
\text { high }\end{array}$ & $\begin{array}{l}\text { Consistent } \\
\left(1^{2}=41 \%\right)\end{array}$ & $\begin{array}{l}\text { Infants with acute diarrhea, not } \\
\text { severely malnourished, in LMICs }\end{array}$ & Moderate & - & - & $-0.18[-0.56,0.19]$ \\
\hline 1 & Persistent & $\mathrm{RCT}$ & Single study of moderate quality & - & $\begin{array}{c}\text { Non-malnourished, non-breastfed } \\
\text { infants with persistent diarrhea in } \\
\text { LMICs }\end{array}$ & Low & - & - & $-0.25(-0.73,0.24)$ \\
\hline \multicolumn{7}{|c|}{ OUTCOME: WEIGHT GAIN } & & & $\begin{array}{c}\text { Standardized } \\
\text { Mean Difference }\end{array}$ \\
\hline 2 & Acute & RCT & $\begin{array}{l}\text { Only two studies, of moderate to high } \\
\text { quality }\end{array}$ & $\begin{array}{l}\text { Consistent } \\
\left(I^{2}=0 \%\right)\end{array}$ & $\begin{array}{l}\text { Infants with acute diarrhea, not } \\
\text { severely malnourished, in LMICs }\end{array}$ & Moderate & - & - & $-0.02[-0.29,0.25]$ \\
\hline 1 & Persistent & RCT & Single study of moderate quality & - & $\begin{array}{l}\text { Non-malnourished, non-breastfed } \\
\text { infants with persistent diarrhea in } \\
\text { LMICs }\end{array}$ & Low & - & - & $0.39(-0.09,0.87)$ \\
\hline \multicolumn{7}{|c|}{ OUTCOME: TREATMENT FAILURE } & & & Risk Ratio \\
\hline 6 & Acute & RCT & $\begin{array}{l}\text { Study quality ranges from moderate to } \\
\text { high; two studies report zero event } \\
\text { counts in both groups }\end{array}$ & $\begin{array}{l}\text { Consistent } \\
\left(1^{2}=0 \%\right)\end{array}$ & $\begin{array}{c}\text { Infants and young children }(\leq 48 \mathrm{~m}) \\
\text { with acute diarrhea, not severely } \\
\text { malnourished, in LMICs }\end{array}$ & Moderate & 30 & 31 & $1.08[0.71,1.64]$ \\
\hline 1 & Persistent & $\mathrm{RCT}$ & Single study of moderate quality & - & $\begin{array}{l}\text { Non-malnourished, non-breastfed } \\
\text { infants with persistent diarrhea in } \\
\text { LMICs }\end{array}$ & Low & 4 & 15 & $0.27[0.10,0.74]$ \\
\hline
\end{tabular}


Table 3 Quality assessment of studies on lactose-free versus lactose-containing liquid feeds

QUALITY ASSESSMENT

\begin{tabular}{|c|c|c|c|c|c|c|c|c|c|}
\hline \multirow[b]{2}{*}{$\begin{array}{c}\text { Number } \\
\text { of } \\
\text { studies }\end{array}$} & \multirow[b]{2}{*}{$\begin{array}{l}\text { Diarrhea } \\
\text { mode }\end{array}$} & \multicolumn{5}{|c|}{ QUALITY ASSESSMENT } & \multicolumn{3}{|c|}{ SUMMARY OF FINDINGS } \\
\hline & & Design & Limitations & Consistency & Generalizability to population of interest & $\begin{array}{l}\text { Overall } \\
\text { quality of } \\
\text { evidence }\end{array}$ & $\begin{array}{l}\text { Number of events } \\
\text { in intervention } \\
\text { group }\end{array}$ & $\begin{array}{l}\text { Number of } \\
\text { events in } \\
\text { control group }\end{array}$ & $\begin{array}{l}\text { Effect size }(95 \% \\
\text { Cl) }\end{array}$ \\
\hline \multicolumn{7}{|c|}{ OUTCOME: DURATION OF DIARRHEA } & & & $\begin{array}{l}\text { Standardized } \\
\text { Mean Difference }\end{array}$ \\
\hline 5 & Acute & $\mathrm{RCT}$ & $\begin{array}{l}\text { Study quality } \\
\text { ranges from } \\
\text { moderate to high }\end{array}$ & $\begin{array}{l}\text { Heterogeneous } \\
\qquad\left(1^{2}=60 \%\right)\end{array}$ & $\begin{array}{l}\text { Infants and young children }(\leq 24 \mathrm{~m}) \text { with acute } \\
\text { diarrhea, without severe malnutrition, in LMICs }\end{array}$ & Moderate & - & - & $-0.36[-0.62,-0.10]$ \\
\hline 0 & Persistent & RCT & No studies & - & - & - & - & - & - \\
\hline \multicolumn{7}{|c|}{ OUTCOME: STOOL OUTPUT } & & & $\begin{array}{c}\text { Standardized } \\
\text { Mean Difference }\end{array}$ \\
\hline 3 & Acute & $\mathrm{RCT}$ & $\begin{array}{l}\text { Study quality } \\
\text { ranges from } \\
\text { moderate to high }\end{array}$ & $\begin{array}{l}\text { Heterogeneous } \\
\qquad\left(1^{2}=76 \%\right)\end{array}$ & $\begin{array}{l}\text { Infants and young children }(\leq 24 \mathrm{~m}) \text { with acute } \\
\text { diarrhea, without severe malnutrition, in LMICs }\end{array}$ & Moderate & - & - & $-0.26[-0.80,0.28]$ \\
\hline 0 & Persistent & RCT & No studies & - & - & - & - & - & - \\
\hline \multicolumn{7}{|c|}{ OUTCOME: WEIGHT GAIN } & & & $\begin{array}{c}\text { Standardized } \\
\text { Mean Difference }\end{array}$ \\
\hline 3 & Acute & RCT & $\begin{array}{l}\text { Study quality } \\
\text { ranges from } \\
\text { moderate to high }\end{array}$ & $\begin{array}{l}\text { Heterogeneous } \\
\qquad\left(1^{2}=41 \%\right)\end{array}$ & $\begin{array}{l}\text { Infants and young children }(\leq 24 \mathrm{~m}) \text { with acute } \\
\text { diarrhea, not severely malnourished, in LMICs }\end{array}$ & Moderate & - & - & $0.05[-0.22,0.33]$ \\
\hline 1 & Persistent & RCT & $\begin{array}{l}\text { Single study of low } \\
\text { quality }\end{array}$ & - & $\begin{array}{c}\text { Infants and young children }(\leq 2 \mathrm{~m}) \text { with persistent } \\
\text { diarrhea, not dehydrated or severely } \\
\text { malnourished, in LMICs }\end{array}$ & Very low & - & - & $0.90(0.07,1.73)$ \\
\hline \multicolumn{7}{|c|}{ OUTCOME: TREATMENT FAILURE } & & & Risk Ratio \\
\hline 7 & Acute & RCT & $\begin{array}{l}\text { Study quality } \\
\text { ranges from low to } \\
\text { high }\end{array}$ & $\begin{array}{l}\text { Consistent } \\
\left(1^{2}=0 \%\right)\end{array}$ & $\begin{array}{l}\text { Infants and young children }(\leq 24 \mathrm{~m}) \text { with acute } \\
\text { diarrhea, not severely malnourished, in LMICs }\end{array}$ & Moderate & 50 & 57 & $0.53[0.40,0.70]$ \\
\hline 2 & Persistent & RCT & $\begin{array}{l}\text { Only two studies, of } \\
\text { low and high } \\
\text { quality }\end{array}$ & $\begin{array}{l}\text { Consistent } \\
\left(1^{2}=0 \%\right)\end{array}$ & $\begin{array}{l}\text { Infants and young children }(\leq 36 \mathrm{~m}) \text { with persistent } \\
\text { diarrhea, not severely malnourished, in LMICs }\end{array}$ & Low & 4 & 11 & $0.17[0.06,0.48]$ \\
\hline
\end{tabular}


were consistent in direction (Figure 2). No effect of lactose-free liquid feeds was shown in the pooled results from three studies on stool output $[16,34,35]$ or from three studies on weight change $[16,35,36]$, but the evidence from seven studies [16,23,32-36] showed a statistically significant reduction of $47 \%$ in the risk of treatment failure (RR: 0.53; 95\%CI: 0.40 to 0.70; $\mathrm{p}<0.0001$ ). Effect sizes and their statistical significance varied across studies but were consistent in direction with the exception of one study (Figure 3). The overall quality of evidence for all four outcomes was assessed as moderate.

\section{Persistent diarrhea}

Two studies compared lactose-free to lactose-containing liquid feeds among children with persistent diarrhea and without severe malnutrition: one compared lactase-treated milk with regular milk [37] and the other compared lactose-free semi-elemental formulas to regular milk [38]. No data were available for the outcomes of diarrhea duration or stool output. Data on weight gain were available only from the study of semi-elemental formulas and showed a large and statistically significant effect of these formulas compared to milk (SMD: 0.90; 95\%CI: 0.07 to 1.73; $\mathrm{p}=0.03$ ), but this evidence was assessed as very low quality because of the study's high and differential attrition rates across study groups (Additional File 2). The pooled result from both studies showed a large and statistically significant effect of lactose-free liquid feeds in reducing the risk of treatment failure (RR: 0.17 ; $95 \%$ CI: 0.06 to 0.48 ; $\mathrm{p}=0.0008$ ), but the overall quality of this evidence was assessed as low.

\section{Lactose-free liquid feeds versus lactose-containing mixed diets \\ Acute diarrhea}

Two trials compared lactose-free liquid feeds to lactosecontaining mixed diets among non-malnourished children with acute diarrhea: one compared lactose-hydrolyzed milk to a combination of regular milk and wheat noodles [35] and the other compared soy-based formula to a mixture of potato and carrot flours, milk powder, sugar and vegetable oil [39]. Data available from the single study reporting on duration, stool output and weight change reported a statistically significant increased duration (SMD: 0.75 ; 95\%CI: 0.22 to $1.28 ; \mathrm{p}=0.006$ ) and increased stool output (SMD: 0.62; 95\%CI: 0.09 to 1.14; $\mathrm{p}=0.02$ ) with lactose-free liquid feeds compared to mixed diets (Table 4), but the overall quality of evidence for all three outcomes was assessed as low given that no other studies were included in the analysis. The pooled result from both studies showed no significant difference in the risk of treatment failure, with the quality of evidence for this outcome also assessed as low given the low number of studies included and the heterogeneity of their effect estimates.

\section{Persistent diarrhea}

Two trials conducted among malnourished, weaned children with persistent diarrhea compared soy-based formula with a mixture of rice, lentils, and yogurt, with the later trial also adding diluted buffalo milk to the mixed diet $[40,41]$. No statistically significant effects of the soy-based formula were shown in the single study reporting on duration [41] or in the pooled results from both studies for stool output, weight gain or treatment failure. The quality of evidence was assessed as low for all outcomes, given the low number and the heterogeneity of the study-specific estimates included.

\section{Commercially prepared or specialized ingredients versus home-available ingredients Acute diarrhea}

Nine trials conducted among children with acute diarrhea compared diets that contained commercial preparations or specialized ingredients with diets comprised of home-available foods and ingredients.

The commercial/specialized diets under study included proprietary cow's milk-based, rice-based, soybased, or lactose-free casein-based formulas in seven studies [17,23,39,42-45]; lactose-hydrolyzed cow's milk with or without wheat noodles in one study [35]; and locally available foods combined with soy protein isolate in one study [46]. The home-available diets under study

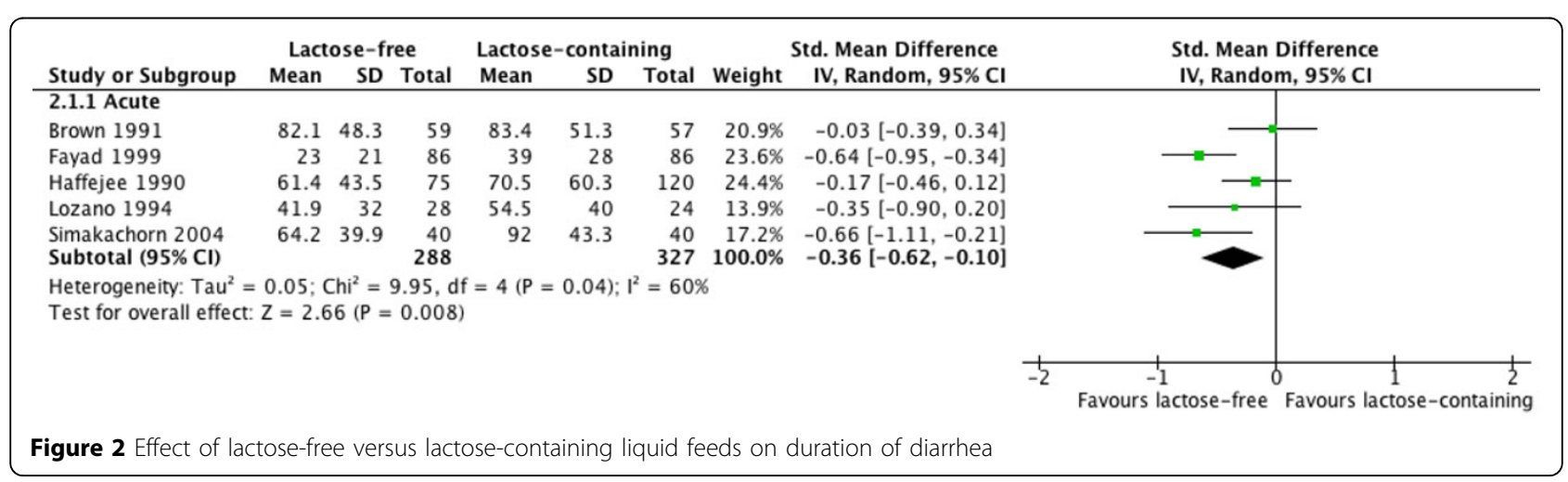




\begin{tabular}{|c|c|c|c|c|c|c|c|c|}
\hline $\begin{array}{l}\text { Study or Subgroup } \\
2.4 .1 \text { Acute diarrhea }\end{array}$ & \multicolumn{2}{|c|}{ Lactose-free } & \multicolumn{2}{|c|}{ Lactose-containing } & Weight & $\begin{array}{l}\text { Risk Ratio } \\
\text { M-H, Random, } 95 \% \mathrm{Cl} \\
\end{array}$ & \multicolumn{2}{|c|}{$\begin{array}{c}\text { Risk Ratio } \\
\text { M-H, Random, } 95 \% \mathrm{Cl}\end{array}$} \\
\hline Brown 1991 & 7 & 59 & 5 & $57-2 \rightarrow>0$ & $6.9 \%$ & $1.35[0.46,4.02]$ & & \\
\hline Fayad 1999 & 2 & 90 & 6 & 94 & $3.3 \%$ & $0.35[0.07,1.68]$ & & — \\
\hline Lifshitz 1991 & 9 & 30 & 13 & 20 & $20.2 \%$ & $0.46[0.24,0.87]$ & $\longrightarrow$ & \\
\hline Lozano 1994 & 1 & 29 & 2 & 25 & $1.5 \%$ & $0.43[0.04,4.48]$ & & \\
\hline Naidoo 1981 & 4 & 56 & 14 & 56 & $7.4 \%$ & $0.29[0.10,0.81]$ & - & \\
\hline Rajah 1988 & 25 & 56 & 13 & 16 & $57.8 \%$ & $0.55[0.38,0.80]$ & - & \\
\hline $\begin{array}{l}\text { Simakachorn } 2004 \\
\text { Subtotal }(95 \% \mathrm{Cl})\end{array}$ & 2 & $\begin{array}{r}40 \\
360\end{array}$ & 4 & $\begin{array}{r}40 \\
308\end{array}$ & $\begin{array}{r}3.0 \% \\
100.0 \%\end{array}$ & $\begin{array}{c}0.50[0.10,2.58] \\
0.53[0.40,0.70]\end{array}$ & & \\
\hline \multicolumn{9}{|c|}{$\begin{array}{l}\text { Heterogeneity: } \operatorname{Tau}^{2}=0.00 ; \mathrm{Chi}^{2}=4.75, \mathrm{df}=6(\mathrm{P}=0.58) ; \mathrm{I}^{2}=0 \% \\
\text { Test for overall effect: } \mathrm{Z}=4.42(\mathrm{P}<0.0001)\end{array}$} \\
\hline \multicolumn{9}{|c|}{ 2.4.2 Persistent diarrhea } \\
\hline Penny 1989 & 1 & 31 & 4 & 33 & $24.3 \%$ & $0.27[0.03,2.25]$ & & \\
\hline $\begin{array}{l}\text { Romer } 1989 \\
\text { Subtotal }(95 \% \mathrm{Cl})\end{array}$ & 3 & $\begin{array}{l}42 \\
73\end{array}$ & 7 & $\begin{array}{l}14 \\
47\end{array}$ & $\begin{array}{r}75.7 \% \\
100.0 \%\end{array}$ & $\begin{array}{r}0.14[0.04,0.48] \\
0.17[0.06,0.48]\end{array}$ & & \\
\hline \multicolumn{9}{|c|}{ 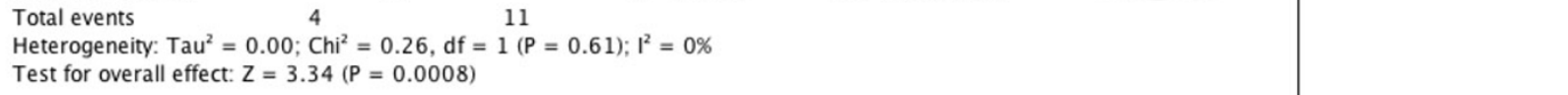 } \\
\hline & & & & & & & $\begin{array}{cc}0.05 & 0.2 \\
\text { Favours lactose-free }\end{array}$ & 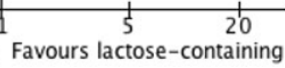 \\
\hline
\end{tabular}

included regular cow's milk with [35] or without wheat noodles $[23,35]$ in two studies; chicken-containing formulations in two studies $[17,44]$; rice and lentils or beans in two studies $[42,46]$; porridges made from wheat, potato, maize or carrot flours in two studies $[39,43]$; and boiled rice alone in one study [45]. All studies excluded children with severe malnutrition.

The pooled results from three studies reporting on duration $[35,42,45]$, four studies reporting on stool output $[17,35,44,45]$, five studies reporting on weight gain $[17,35,42,44,45]$ and eight studies reporting on treatment failure $[23,35,39,42-46]$ showed no statistically significant effect of commercial/specialized diets compared to home available diets on any outcome (Table 5). The overall quality of evidence was assessed as moderate for all four outcomes.

When we restricted these analyses to only those studies in which both the intervention and control diets were both lactose-free, no statistically significant effects of the commercial/specialized diets were shown with respect to duration, stool output or treatment failure, but the pooled result from three studies reporting on weight gain $[17,44,45]$ showed a statistically significant reduction in weight gain with commercial/specialized diets compared to home-available diets (SMD: -0.30 ; $95 \% \mathrm{CI}$ : -0.55 to -0.04; $\mathrm{p}=0.02$ ) (Additional File 4).

\section{Persistent diarrhea}

Six studies conducted among children with persistent diarrhea compared diets containing commercial preparations or specialized ingredients with diets comprised of home-available foods and ingredients.

The commercial/specialized diets included proprietary rice-based, soy-based, lactose-free whey-based, or amino acid-based formulas in four studies [18,38,40,41]; lactose-hydrolyzed milk in one study [37]; and locally available foods combined with lactalbumin hydrolysate in one study [47]. The home-available diets included a rice, lentil and yogurt mixture with or without diluted buffalo milk in two studies [40,41]; chicken-containing formulations in two studies [18,47]; and cow's milk in two studies $[37,38]$.

The pooled result from three studies reporting on duration $[18,41,47]$ and on stool output $[18,40,41]$ among moderately or severely malnourished children showed no statistically significant effects of commercial/ specialized diets compared to home-available diets. The overall quality of evidence for both outcomes was assessed as moderate. No statistically significant effects were shown from the pooled results of four studies reporting on weight gain $[18,37,40,41]$ or the five studies reporting on treatment failure $[18,37,38,40,41]$. The pooled results for weight gain and treatment failure included two studies conducted among children who were normal or moderately malnourished children [37,38], two studies among moderately or severely malnourished children $[40,41]$, and one study among only severely malnourished children [18]. Stratifying the studies by nutritional status, there continued to be no statistically significant effects among moderately or severely malnourished children, or among only severely malnourished children, but a significant increase in weight gain and a significant decrease in treatment failure risk was shown among normal or moderately malnourished children $[37,38]$. However, the overall quality of evidence for this stratum was assessed as very low, as in the analysis of the same two studies in the 
Table 4 Quality assessment of studies on lactose-free liquid feeds versus lactose-containing mixed diets

\begin{tabular}{|c|c|c|c|c|c|c|c|c|c|}
\hline \multirow[b]{2}{*}{$\begin{array}{l}\text { Number } \\
\text { of } \\
\text { studies }\end{array}$} & \multirow[b]{2}{*}{$\begin{array}{l}\text { Diarrhea } \\
\text { mode }\end{array}$} & \multicolumn{5}{|c|}{ QUALITY ASSESSMENT } & \multicolumn{3}{|c|}{ SUMMARY OF FINDINGS } \\
\hline & & Design & Limitations & Consistency & $\begin{array}{l}\text { Generalizability to population of } \\
\text { interest }\end{array}$ & $\begin{array}{l}\text { Overall } \\
\text { quality of } \\
\text { evidence }\end{array}$ & $\begin{array}{l}\text { Number of events } \\
\text { in intervention } \\
\text { group }\end{array}$ & $\begin{array}{l}\text { Number of } \\
\text { events in } \\
\text { control group }\end{array}$ & $\begin{array}{l}\text { Effect size }(95 \% \\
\text { Cl) }\end{array}$ \\
\hline \multicolumn{7}{|c|}{ OUTCOME: DURATION OF DIARRHEA } & & & $\begin{array}{l}\text { Standardized } \\
\text { Mean Difference }\end{array}$ \\
\hline 1 & Acute & RCT & $\begin{array}{l}\text { Single study of high } \\
\text { quality }\end{array}$ & - & $\begin{array}{c}\text { Non-malnourished infants and young } \\
\text { children }(\leq 24 \mathrm{~m}) \text { with acute diarrhea in } \\
\text { LMICs }\end{array}$ & Low & - & - & $0.75[0.22,1.28]$ \\
\hline 1 & Persistent & $\mathrm{RCT}$ & $\begin{array}{l}\text { Single study of moderate } \\
\text { quality }\end{array}$ & - & $\begin{array}{l}\text { Malnourished weaned infants and young } \\
\text { children }(\leq 36 \mathrm{~m}) \text { with persistent diarrhea } \\
\text { in LMICs }\end{array}$ & Low & - & - & $0.28[-0.35,0.90]$ \\
\hline \multicolumn{7}{|c|}{ OUTCOME: STOOL OUTPUT } & & & $\begin{array}{l}\text { Standardized } \\
\text { Mean Difference }\end{array}$ \\
\hline 1 & Acute & RCT & $\begin{array}{l}\text { Single study of high } \\
\text { quality }\end{array}$ & - & $\begin{array}{c}\text { Non-malnourished infants and young } \\
\text { children }(\leq 24 \mathrm{~m}) \text { with acute diarrhea in } \\
\text { LMICs }\end{array}$ & Low & - & - & $0.62[0.09,1.14]$ \\
\hline 2 & Persistent & RCT & $\begin{array}{l}\text { Only two studies, both of } \\
\text { moderate quality }\end{array}$ & $\begin{array}{l}\text { Heterogeneous } \\
\qquad\left(I^{2}=50 \%\right)\end{array}$ & $\begin{array}{l}\text { Malnourished weaned infants and young } \\
\text { children }(\leq 36 \mathrm{~m}) \text { with persistent diarrhea } \\
\text { in LMICs }\end{array}$ & Low & - & - & $0.22[-0.33,0.78]$ \\
\hline \multicolumn{7}{|c|}{ OUTCOME: WEIGHT GAIN } & & & $\begin{array}{l}\text { Standardized } \\
\text { Mean Difference }\end{array}$ \\
\hline 1 & Acute & $\mathrm{RCT}$ & $\begin{array}{l}\text { Single study of high } \\
\text { quality }\end{array}$ & - & $\begin{array}{c}\text { Non-malnourished infants and young } \\
\text { children }(\leq 24 \mathrm{~m}) \text { with acute diarrhea in } \\
\text { LMICs }\end{array}$ & Low & - & - & $0.21[-0.31,0.72]$ \\
\hline 2 & Persistent & RCT & $\begin{array}{l}\text { Only two studies, both of } \\
\text { moderate quality }\end{array}$ & $\begin{array}{l}\text { Heterogeneous } \\
\qquad\left(1^{2}=94 \%\right)\end{array}$ & $\begin{array}{l}\text { Malnourished weaned infants and young } \\
\text { children }(\leq 36 \mathrm{~m}) \text { with persistent diarrhea } \\
\text { in LMICs }\end{array}$ & Low & - & - & $-0.35[-2.00,1.31]$ \\
\hline \multicolumn{7}{|c|}{ OUTCOME: TREATMENT FAILURE } & & & Risk Ratio \\
\hline 2 & Acute & RCT & $\begin{array}{c}\text { Only two studies, ranging } \\
\text { from moderate to high } \\
\text { quality }\end{array}$ & $\begin{array}{l}\text { Heterogeneous } \\
\qquad\left(1^{2}=60 \%\right)\end{array}$ & $\begin{array}{c}\text { Non-malnourished infants and young } \\
\text { children }(\leq 24 \mathrm{~m}) \text { with acute diarrhea in } \\
\text { LMICs }\end{array}$ & Low & 7 & 3 & $1.79[0.15,20.66]$ \\
\hline 2 & Persistent & RCT & $\begin{array}{l}\text { Only two studies, both of } \\
\text { moderate quality }\end{array}$ & $\begin{array}{l}\text { Heterogeneous } \\
\qquad\left(1^{2}=72 \%\right)\end{array}$ & $\begin{array}{c}\text { Malnourished weaned infants and young } \\
\text { children }(\leq 36 \mathrm{~m}) \text { with persistent diarrhea } \\
\text { in LMICs }\end{array}$ & Low & 6 & 7 & $1.25[0.07,23.66]$ \\
\hline
\end{tabular}


Table 5 Quality assessment of studies on commercial/specialized ingredients versus home-available ingredients

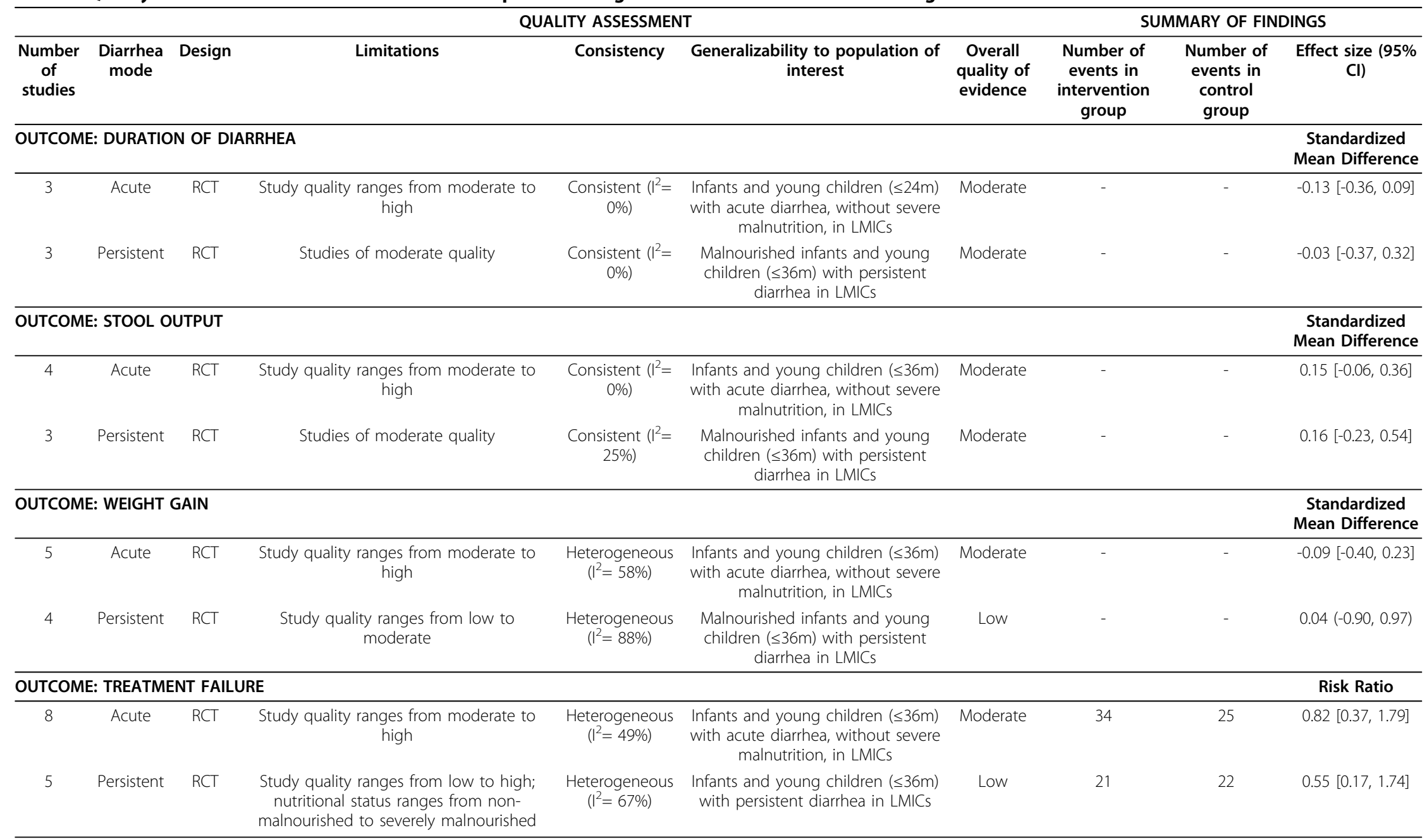


comparison of lactose-free with lactose-containing liquid feeds in persistent diarrhea, reported above.

When we restricted these analyses to only those two studies in which the commercial/specialized diet and the home-available diet were both lactose-free $[18,47]$, no statistically significant effects were shown with respect to any of the four outcomes, though the overall quality of evidence for these outcomes was low. Both studies were conducted among severely malnourished children.

\section{Discussion}

We used data from 29 randomized controlled trials conducted in low- and middle-income countries to assess the evidence for several approaches to the dietary management of childhood diarrhea, including lactose reduction and avoidance and the use of home-available foods. We found evidence of low-to-moderate quality suggesting that among children with acute diarrhea, diluting or fermenting a lactose-containing liquid feed does not affect diarrhea duration, stool output, weight gain or risk of treatment failure compared with an ordinary lactosecontaining liquid feed given at full strength. In contrast, we found moderate quality evidence suggesting that lactose-free liquid feeds reduce duration and the risk of treatment failure compared to lactose-containing liquid feeds in acute diarrhea. Only limited evidence of low quality was available to assess either of these two approaches in persistent diarrhea, or to assess lactosefree liquid feeds compared to lactose-containing mixed diets in either acute or persistent diarrhea. Our analyses of all studies on the use of commercially prepared or specialized ingredients compared to home-available ingredients found low-to-moderate quality evidence of no effect on any outcome in either acute or persistent diarrhea. When we restricted these analyses to studies where both the commercial/specialized and the home-available diets were lactose-free, weight gain in children with acute diarrhea was shown to be greater among those fed with a home-available diet.

The present review supplements the existing literature on dietary management of childhood diarrhea in at least two ways. First, we have focused our analyses exclusively on children in low- and middle-income countries, where the global burden of diarrhea incidence and mortality is concentrated and where financial and logistic barriers to accessing proprietary infant formulas and specialized ingredients are greatest, including in hospital settings. While severely malnourished children were excluded from the majority of trials we analyzed, nearly all included moderately malnourished children in their study populations and only one trial was restricted to well-nourished children. The results of this review thus generalize directly to the settings in which most children affected by diarrhea live. Secondly, we have attempted to disaggregate the effects of various approaches to dietary management by duration of diarrhea at study enrolment, recognizing that persistent post-infectious diarrhea may constitute a related but distinct pathophysiology from that of acute diarrhea, involving prolonged intestinal mucosal injury and delayed mucosal regeneration which increase the risk of chronic malnutrition and growth failure and may also inhibit neurodevelopment [48]. Previously reviewed evidence from community-based cohort studies in Asia, Africa and Latin America suggests that persistent diarrhea accounts for 3\% to $20 \%$ of all childhood diarrheal episodes $[9,49]$ and between one third to one half of diarrhea mortality [9]. We therefore sought to separately investigate the evidence for the dietary management of this important subset of the total diarrheal burden.

A previous meta-analysis of studies on the use of nonhuman milks for treating acute diarrhea in children was published in 1994 [12]. In addition to our inclusion of new studies conducted since then, our analyses also differ from those in the previous review with respect to our narrower study population and by our inclusion of studies evaluating acidified or fermented milk products. Nonetheless, our finding of no apparent effect of reducing the lactose content of lactose-containing liquid feeds in acute diarrhea is consistent with the results of the previous review which showed no difference in duration, stool output or risk of treatment failure when comparing undiluted to diluted milks, though weight gain was shown to be higher among children fed undiluted milks. Similarly, our findings of increased duration and treatment failure risk among children with acute diarrhea consuming lactose-containing instead of lactose-free liquid feeds are consistent with the earlier analyses, though the previous review also found stool output to be higher among those fed lactose-containing diets. While transient lactase deficiency may be common among children with acute diarrhea, lactose intolerance does not always develop. The previous review concluded that feeding with lactose-containing milks can be safely and effectively continued in the majority of children with acute diarrhea, and the results of our analyses do not contradict this conclusion. However, the results of both reviews indicate that lactose intolerance is indeed an important complication in some cases. Stratified analyses in the previous review showed that the effects of avoiding lactose were largely restricted to those children with severe dehydration at enrolment or to those studies conducted earlier than 1985, before the current protocol of oral rehydration solution plus continued feeding was widely adopted. In the present review, none of the children included in the analyses on the lactose content of liquid feeds were severely dehydrated at enrolment and only two of the studies included in these analyses were conducted before 1985 [25,33], but most children were at 
least moderately malnourished. Thus, the particular characteristics associated with an increased risk of lactose intolerance among children with diarrhea remain unclear.

The potential benefits of feeding yogurt during diarrhea have been considered in previous reviews of the literature $[8,12,14]$, but we were able to find and include only four randomized controlled trials of acidified or fermented milk products that were compatible with the comparisons and outcomes of interest to the present review, and these trials contributed to our analyses on the lactose content of liquid feeds. The two trials reporting on the outcome of duration in acute diarrhea $[26,29]$ both showed significant decreases in duration with the yogurt feeds compared to the regular milk feeds (Additional File 4). We excluded from our study one recent trial from Brazil that compared yogurt to several lactose-free liquid feeds among children with persistent diarrhea and found a significant beneficial effect of the yogurt-based diet with respect to diarrhea duration and stool output [50]. However, the yogurt-based diet inadvertently included a far higher concentration of zinc than any of the lactose-free diets. While the therapeutic dose of zinc may have been largely responsible for these results, any additional effects of the yogurt-based feed remain unknown.

Additionally, beyond our analyses comparing the lactose-content of liquid feeds, we found insufficient evidence to meaningfully evaluate other strategies for reducing lactose intake rather than eliminating lactose from the diet altogether. The partial replacement of milk with staple foods such as cereals and legumes reduces the overall lactose content of the diet, can better maintain or increase energy and protein intake, and may also improve stool consistency due to higher fiber intake [35,51]. Results from a large multi-country cohort study conducted in Asia and Latin America in 1996 suggest that mixed diets comprised of local cereals, vegetable oil and milk or yogurt can be used effectively in $65 \%$ (95\%CI: $61 \%-70 \%$ ) of young, malnourished children with persistent diarrhea [52]. In the present review, we sought to evaluate the evidence for using lactosecontaining mixed diets compared to lactose-free liquid feeds for managing childhood diarrhea, but we found too few randomized controlled trials to enable such an evaluation. Further experimental evidence on both the use of acidified or fermented milk products and the use of milk-staple mixtures may confirm these feasible approaches as effective for managing diarrhea in children for whom lactose intake is problematic but for whom the complete avoidance of milk would pose significant nutritional risk.

In our final set of analyses, we deliberately focused our inquiry on the pragmatic aspect of treating childhood diarrhea in low- and middle-income countries and we found no evidence to support the use of proprietary formulas or specialized ingredients over the use of locally produced and readily available foods in the treatment of either acute or persistent diarrhea. Moreover, this finding held even when we narrowed our analyses to studies in which both the commercial/specialized diets and the home-available diets were lactose-free. Notably, we found evidence suggesting that weight gain during acute diarrhea was better among children being fed lactosefree home-available ingredients than among those consuming lactose-free commercial/specialized diets. The practical implication of these findings is extremely important for resource-constrained settings generally and should inform efforts to improve home-based management of childhood diarrhea in particular.

In summary, the results of our analyses suggest that lactose reduction among children consuming lactosecontaining liquid feeds has little effect on clinical outcomes in childhood diarrhea, but the avoidance of lactose altogether may be important in some cases. However, further evidence is needed to fully assess the potential clinical and nutritional effects of reducing lactose intake through the use of yogurt or milk-staple mixtures rather than by eliminating milk from the diet entirely. Finally, and perhaps most importantly, our analyses indicate that diets comprised of home-available ingredients can be used at least as effectively as diets comprised of commercial preparations or specialized ingredients for managing both acute and persistent diarrhea, even among those children from whom lactose avoidance may be necessary.

Our review suffers from some limitations. The dietary comparisons made in many existing studies on dietary management of childhood diarrhea were not compatible with the comparisons we ultimately identified for this review and were therefore not included (Additional File 3). Other approaches that have been evaluated by randomized controlled trial in low- and middle-income settings include the use of amylase-rich flours in cereal-based porridges to decrease viscosity and thus increase nutrient density and children's nutrient intake [53-55], and incorporating into mixed diets specific ingredients thought or known to have antidiarrheal properties, such as green banana [56,57]. A synthesis of the evidence for the full range of management options would best inform guidelines for optimal diet selection for childhood diarrhea treatment. It would also have been useful to investigate other dietary characteristics such as fibre content or osmolality, but there were insufficient data available across studies to enable this. Additionally, all but one [16] of the 29 studies that we included in our review were conducted in 1999 or earlier and only six studies $[18,37,38,40,41,47]$ focused on persistent diarrhea. However, rather than a consequence of our review methods, we believe this limitation is almost 
certainly a consequence of the limited attention paid to childhood diarrhea in recent years.

\section{Conclusions}

Continued feeding is important for limiting the nutritional consequences of decreased intake, digestion and absorption of essential nutrients during diarrheal illness. Among children in low- and middle-income countries, where the dual burden of diarrhea and malnutrition is greatest and where access to proprietary formulas and specialized ingredients is limited, continued breastfeeding should be encouraged and the use of locally available ageappropriate foods should be promoted for the majority of acute diarrhea cases. Lactose intolerance is an important complication in some cases, but even among those children for whom lactose avoidance may be necessary, nutritionally complete diets comprised of locally available ingredients can be used as least as effectively as commercial preparations or specialized ingredients. These same conclusions may also apply to the dietary management of children with persistent diarrhea, but the evidence remains limited. Overall, our review is supportive of current WHO/UNICEF recommendations for continued breastfeeding and administration of home-available ageappropriate foods to children 6 to 59 months of age with diarrhea.

\section{Additional material}

Additional File 1: Electronic search strategy for Medline, Embase and AMED databases

Additional File 2: Abstracted data from all 29 studies included in the quantitative data synthesis

Additional File 3: Eligible studies not included in the quantitative data synthesis

Additional File 4: Forest plots for all comparisons and outcomes

\section{Competing interests}

The authors declare that they have no competing interests.

\section{Authors' contributions}

ZAB conceived of the study; MFG, KW and ZAB wrote the protocol; MFG and KW conducted the literature searches, abstracted the data and assessed study quality, with DGB resolving any discrepancies; MFG analyzed the data and wrote the first draft of the manuscript; all authors revised the draft and approved the final manuscript.

\section{Declarations}

The publication costs for this supplement were funded by a grant from the Bill \& Melinda Gates Foundation to the US Fund for UNICEF (grant 43386 to "Promote evidence-based decision making in designing maternal, neonatal, and child health interventions in low- and middle-income countries"). The Supplement Editor is the principal investigator and lead in the development of the Lives Saved Tool (LiST), supported by grant 43386. He declares that he has no competing interests.

This article has been published as part of BMC Public Health Volume 13 Supplement 3, 2013: The Lives Saved Tool in 2013: new capabilities and applications. The full contents of the supplement are available online at http://www.biomedcentral.com/bmcpublichealth/supplements/13/S3.

\section{Authors' details}

${ }^{1}$ Centre for Global Child Health, The Hospital for Sick Children, Toronto, ON, Canada. ${ }^{2}$ Dalla Lana School of Public Health, University of Toronto, Toronto, ON, Canada. ${ }^{3}$ Department of Paediatrics, University of Toronto, Toronto, ON, Canada. ${ }^{4}$ Division of Women and Child Health, Aga Khan University Hospital, Karachi, Pakistan.

Published: 17 September 2013

\section{References}

1. Liu L, Johnson HL, Cousens S, Perin J, Scott S, Lawn JE, Rudan I, Campbell H, Cibulskis R, Li M, et al: Global, regional, and national causes of child mortality: an updated systematic analysis for 2010 with time trends since 2000. Lancet 2012, 379(9832):2151-2161.

2. UNICEF/WHO: Joint statement: clinical management of acute diarrhoea. New York and Geneva: United Nations Children's Fund and the World Health Organization; 2004, 8.

3. UNICEF/WHO: Diarrhoea: why children are still dying and what can be done. New York and Geneva: United Nations Children's Fund and the World Health Organization; 2009, 58.

4. Chung AW, Viscorova B: The effect of early oral feeding versus early oral starvation on the course of infantile diarrhea. The Journal of Pediatrics 1948, 33(1):14-22.

5. Brown KH: Dietary management of acute childhood diarrhea: Optimal timing of feeding and appropriate use of milks and mixed diets. Journal of Pediatrics 1991, 118(4 II SUPPL.):S92-S98.

6. Murphy MS: Guidelines for managing acute gastroenteritis based on a systematic review of published research. Archives of Disease in Childhood 1998, 79(3):279-284.

7. Gregorio GV, Dans LF, Silvestre MA: Early versus delayed refeeding for children with acute diarrhoea. Cochrane Database Syst Rev 2011, , 7: CD007296.

8. Duggan C, Nurko S: "Feeding the gut": the scientific basis for continued enteral nutrition during acute diarrhea. The Journal of pediatrics 1997, 131(6):801-808.

9. Bhutta ZA, Hendricks KM: Nutritional management of persistent diarrhea in childhood: a perspective from the developing world. Journal of Pediatric Gastroenterology and Nutrition 1996, 22(1):17-37.

10. Lanata CF, Black RE: Diarrheal diseases. In Nutrition and health in developing countries.. 2 edition. Totowa, NJ: Humana Press;Semba RD, Bloem MW 2008:

11. Lifshitz F, Coello-Ramirez P, Gutierrez-Topete G, Cornado-Cornet MC: Carbohydrate intolerance in infants with diarrhea. The Journal of Pediatrics 1971, 79(5):760-767.

12. Brown $\mathrm{KH}$, Peerson JM, Fontaine O: Use of nonhuman milks in the dietary management of young children with acute diarrhea: A meta-analysis of clinical trials. Pediatrics 1994, 93(1):17-27.

13. Gracey M: Nutritional effects and management of diarrhoea in infancy. Acta Paediatrica 1999, 88(430):110-126.

14. Sullivan PB: Nutritional management of acute diarrhea. Nutrition 1998, 14(10):758-762.

15. World Bank Country and Lending Groups. [http://data.worldbank.org/ about/country-classifications/country-and-lending-groups].

16. Simakachorn $N$, Tongpenyai $Y$, Tongtan $O$, Varavithya $W$ : Randomized double-blind clinical trial of a lactose-free and a lactose-containing formula in dietary management of acute childhood diarrhea. Journal of the Medical Association of Thailand 2004, 87(6):641-649.

17. Carías D, Cioccia AM, Hevia P, Romer H, Guerra M, Brito O: Nutrient utilization in children with acute diarrhea fed formulas with chicken or soybean protein [Spanish]. Arch Latinoam Nutr 1999, 49(2):130-137.

18. Nurko S, Garcia-Aranda JA, Fishbein E, Perez-Zuniga MI: Successful use of a chicken-based diet for the treatment of severely malnourished children with persistent diarrhea: A prospective, randomized study. Journal of Pediatrics 1997, 131(3):405-412.

19. Abrams KR, Gillies CL, Lambert PC: Meta-analysis of heterogeneously reported trials assessing change from baseline. Stat Med 2005, 24(24):3823-3844. 
20. Walker N, Fischer-Walker C, Bryce J, Bahl R, Cousens S: Standards for CHERG reviews of intervention effects on child survival. International Journal of Epidemiology 2010, 39(Suppl 1):i21-31.

21. Deeks JJ, Higgins JPT, Altman DG: Chapter 9: Analysing data and undertaking meta-analyses. In Cochrane Handbook for Systematic Reviews of Interventions, Version 5.1.0 Higgins JPT, Green S: The Cochrane Collaboration 2011.

22. Chew F, Penna FJ, Peret Filho LA, Quan C, Lopes MC, Mota JAC, Fontaine $\mathrm{O}$ : Is dilution of cows' milk formula necessary for dietary management of acute diarrhoea in infants aged less than 6 months? Lancet 1993, 341(8839):194-197.

23. Lifshitz F, Neto UF, Garcia Olivo CA, Cordano A, Friedman S: Refeeding of infants with acute diarrheal disease. Journal of Pediatrics 1991, 118(4 II SUPPL.):S99-S108.

24. Pichaipat $V$, Thanomsingh $P$, Assadamongkul $K$, Varavithya W: Effects of amount and concentration of a lactose-containing formula on outcome of infantile diarrhoea. Journal of the Medical Association of Thailand 1986, 69(Suppl 2):132-136.

25. Ransome OJ, Roode $\mathrm{H}$ : Early introduction of milk feeds in acute infantile gastro-enteritis. A controlled study. South African Medical Journal 1984, 65(4):127-128.

26. Touhami M, Boudraa G, Adlaoui M, Telidji Z, Soltana R, Mary JY, Desjeux JF: Is the dilution of milk necessary in benign acute diarrhea in eutrophic infants? [French]. Archives Francaises de Pediatrie 1989, 46(1):25-30.

27. Bhatnagar S, Singh KD, Sazawal S, Saxena SK, Bhan MK: Efficacy of milk versus yogurt offered as part of a mixed diet in acute noncholera diarrhea among malnourished children. Journal of Pediatrics 1998, 132(6):999-1003.

28. Ibanez S, Puentes R, Winter A, Guajardo J, Jeraldo A, Jimenez A: Comparison of three dietetic formulas in infants with acute diarrhea. [Spanish]. Revista Chilena de Pediatria 1986, 57(2):158-163.

29. Singh T: Yoghurt feeding during acute diarrhea. Indian Pediatrics 1987, 24(6):530.

30. Touhami M, Boudraa G, Mary JY, Soltana R, Desjeux JF: Clinical consequences of replacing milk with yogurt in persistent infantile diarrhea. [French]. Annales de Pediatrie 1992, 39(2):79-86.

31. Haffejee IE: Cow's milk-based formula, human milk, and soya feeds in acute infantile diarrhea: A therapeutic trial. Journal of Pediatric Gastroenterology and Nutrition 1990, 10(2):193-198.

32. Lozano JM, Cespedes JA: Lactose vs. lactose free regimen in children with acute diarrhoea: a randomized controlled trial. Archivos Latinoamericanos de Nutricion 1994, 44(1):6-11.

33. Naidoo BT, Chunterpurshad I, Mahyoodeen AB, Pather G: The use of a soy isolate based formula in the treatment of infantile diarrhoea. Journal of International Medical Research 1981, 9(3):232-235.

34. Rajah R, Pettifor JM, Noormohamed M, Venter A, Rosen EU, Rabinowitz L, Stein $\mathrm{H}$ : The effect of feeding four different formulae on stool weights in prolonged dehydrating infantile gastroenteritis. Journal of Pediatric Gastroenterology and Nutrition 1988, 7(2):203-207.

35. Brown KH, Perez F, Gastanaduy AS: Clinical trial of modified whole milk, lactose-hydrolyzed whole milk, or cereal-milk mixtures for the dietary management of acute childhood diarrhea. Journal of Pediatric Gastroenterology and Nutrition 1991, 12(3):340-350.

36. Fayad IM, Hashem M, Hussein A, Abou Zikri M, Abu Zikri M, Santosham M: Comparison of soy-based formulas with lactose and with sucrose in the treatment of acute diarrhea in infants. Archives of Pediatrics and Adolescent Medicine 1999, 153(7):675-680.

37. Penny ME, Paredes $\mathrm{P}$, Brown $\mathrm{KH}$ : Clinical and nutritional consequences of lactose feeding during persistent postenteritis diarrhea. Pediatrics 1989, 84(5):835-844.

38. Romer H, Olivero E, Gomez-Rodriguez G, Velasquez-Avila G, Lea M, Aguero L, Cavazza ME: Effect of carbohydrate composition of semielemental diets on the nutritional recovery of children with chronic diarrhea. Nutrition Reports International 1989, 40(5):843-852.

39. Alarcon P, Montoya R, Perez F, Dongo JW, Peerson JM, Brown KH: Clinical trial of home available, mixed diets versus a lactose-free, soy-protein formula for the dietary management of acute childhood diarrhea. Journal of Pediatric Gastroenterology and Nutrition 1991, 12(2):224-232.

40. Bhutta ZA, Molla AM, Issani Z, Badruddin S, Hendricks K, Snyder JD: Dietary management of persistent diarrhea: Comparison of a traditional ricelentil based diet with soy formula. Pediatrics 1991, 88(5):1010-1018.
41. Bhutta ZA, Molla AM, Issani Z, Badruddin S, Hendricks K, Snyder JD: Nutrient absorption and weight gain in persistent diarrhea: Comparison of a traditional rice-lentil/yogurt/milk diet with soy formula. Journal of Pediatric Gastroenterology and Nutrition 1994, 18(1):45-52.

42. Bhan MK, Arora NK, Khoshoo V, Raj P, Bhatnager S, Sazawal S, Sharma K: Comparison of a lactose-free cereal-based formula and cow's milk in infants and children with acute gastroenteritis. Journal of Pediatric Gastroenterology and Nutrition 1988, 7(2):208-213.

43. Grange AO, Santosham M, Ayodele AK, Lesi FE, Stallings RY, Brown KH: Evaluation of a maize-cowpea-palm oil diet for the dietary management of Nigerian children with acute, watery diarrhea. Acta Paediatr 1994, 83(8):825-832.

44. Maulen-Radovan I, Brown KH, Acosta MA, Fernandez-Varela H: Comparison of a rice-based, mixed diet versus a lactose-free, soy-protein isolate formula for young children with acute diarrhea. Journal of Pediatrics 1994, 125(5 I):699-706.

45. Santosham M, Fayad IM, Hashem M, Goepp JG, Refat M, Sack RB: A comparison of rice-based oral rehydration solution and 'early feeding' for the treatment of acute diarrhea in infants. Journal of Pediatrics 1990, 116(6):868-875.

46. Alarcon P, Montoya R, Rivera J, Perez F, Peerson JM, Brown KH: Effect of inclusion of beans in a mixed diet for the treatment of Peruvian children with acute watery diarrhea. Pediatrics 1992, 90:58-65.

47. Godard C, Bustos M, Munoz M, Nussle D: Value of a chicken-based formula for refeeding of children with protracted diarrhea and malnutrition in a developing country. Journal of Pediatric Gastroenterology and Nutrition 1989, 9(4):473-480.

48. Bhutta ZA, Nelson EA, Lee WS, Tarr PI, Zablah R, Phua KB, Lindley K, Bass D, Phillips A: Recent advances and evidence gaps in persistent diarrhea. Journal of Pediatric Gastroenterology and Nutrition 2008, 47(2):260-265.

49. Moore SR: Update on prolonged and persistent diarrhea in children. Curr Opin Gastroenterol 2011, 27(1):19-23.

50. de Mattos AP, Ribeiro TCM, Mendes PSA, Valois SS, Mendes CMC, Ribeiro HC Jr: Comparison of yogurt, soybean, casein, and amino acidbased diets in children with persistent diarrhea. Nutrition Research 2009, 29(7):462-469.

51. Brown KH, Perez F, Peerson JM, Fadel J, Brunsgaard G, Ostrom KM, MacLean WC Jr: Effect of dietary fiber (soy polysaccharide) on the severity, duration, and nutritional outcome of acute, watery diarrhea in children. Pediatrics 1993, $92(2$ I):241-247.

52. Ashraf H, Bhan MK, Bhatnagar S, Bhutta Z, Brown KH, Dung PT, Fontaine O, Garcia Aranda JA, Issani Z, Ly DT, et al: Evaluation of an algorithm for the treatment of persistent diarrhoea: A multicentre study. Bulletin of the World Health Organization 1996, 74(5):479-489.

53. Darling JC, Kitundu JA, Kingamkono RR, Msengi AE, Mduma B, Sullivan KR, Tomkins AM: Improved energy intakes using amylase-digested weaning foods in Tanzanian children with acute diarrhea. Journal of Pediatric Gastroenterology and Nutrition 1995, 21(1):73-81.

54. Mensah P, Ndiokwelu Cl, Uwaegbute A, Ablordey A, van Boxtel AM, Brinkman C, Nout MJ, Ngoddy PO: Feeding of lactic acid-fermented high nutrient density weaning formula in paediatric settings in Ghana and Nigeria: acceptance by mother and infant and performance during recovery from acute diarrhoea. International Journal of Food Sciences and Nutrition 1995, 46(4):353-362.

55. Mitra AK, Rahman MM, Mahalanabis D, Patra FC, Wahed MA: Evaluation of an energy-dense meal liquefied with amylase of germinated wheat in children with acute watery diarrhoea: A randomized controlled clinical trial. Nutrition Research 1995, 15(7):939-951.

56. Rabbani GH, Larson CP, Islam R, Saha UR, Kabir A: Green bananasupplemented diet in the home management of acute and prolonged diarrhoea in children: a community-based trial in rural Bangladesh. Trop Med Int Health 2010, 15(10):1132-1139.

57. Rabbani GH, Teka T, Zaman B, Majid N, Khatun M, Fuchs GJ: Clinical studies in persistent diarrhea: Dietary management with green banana or pectin in Bangladeshi children. Gastroenterology 2001, 121(3):554-560.

doi:10.1186/1471-2458-13-S3-S17

Cite this article as: Gaffey et al: Dietary management of childhood diarrhea in low- and middle-income countries: a systematic review. BMC Public Health 2013 13(Suppl 3):S17. 